\title{
Comparison and validation of sampling strategies for the molecular microbial analysis of surface microlayers
}

\author{
Michael Cunliffe ${ }^{1, *}$, Emma Harrison ${ }^{2}$, Matthew Salter ${ }^{2}$, Hendrik Schäfer ${ }^{3}$, \\ Robert C. Upstill-Goddard ${ }^{2}$, J. Colin Murrell ${ }^{1}$ \\ ${ }^{1}$ Department of Biological Sciences, University of Warwick, Gibbet Hill Road, Coventry CV4 7AL, UK \\ ${ }^{2}$ Ocean Research Group, School of Marine Science and Technology, Newcastle University, Newcastle-upon-Tyne \\ NE1 7RU, UK \\ ${ }^{3}$ Warwick HRI, University of Warwick, Wellesbourne CV35 9EF, UK
}

\begin{abstract}
A range of sampling methods are available to sample the sea surface microlayer, including mesh screens (MS), glass plates (GP), hydrophobic (PTFE, polytetrafluoroethylene) and hydrophilic (PC, polycarbonate) membranes. We compared bacterial community structures in surface microlayer samples and in subsurface water $(0.4 \mathrm{~m})$ collected using the above sampling methods. Samples were collected from the Tyne Estuary and analysed using DGGE of bacterial 16S rRNA genes. Samples collected using GP and MS were similar to subsurface water samples. Samples collected using PTFE and PC showed distinct differences compared to samples collected using GP and MS and subsurface samples. Membranes sample within the proposed depth range of the actual sea surface microlayer while GP and MS collect deeper samples which therefore also contain subsurface water. There is therefore clear evidence that GP and MS samplers under-represent the surface microlayer. Bacterial and archaeal communities were compared in sea surface microlayer and subsurface samples collected with PC from 3 sites in the Pacific Ocean. Samples were analysed using DGGE of bacterial and archaeal 16S rRNA genes. Bacterial communities in samples collected from the sea surface microlayer at 2 sites on either side of Oahu Island were more similar to each other than to their cognate subsurface samples. Archaeal communities did not show a distinct surface microlayer effect. Data presented here clearly indicate that Bacteria respond significantly to this sea surface microlayer environment and further support the use of PC in sampling surface microlayers.
\end{abstract}

KEY WORDS: Sea surface microlayer · Neuston · Sampling · Bacterioneuston · DGGE · Bacteria · Archaea Resale or republication not permitted without written consent of the publisher

\section{INTRODUCTION}

Molecular biological techniques for the study of the microbial communities of oceans and other aquatic systems are of great importance in contemporary oceanography and limnology (Giovannoni \& Stingl 2005). It is generally accepted that many microbes cannot be cultivated in the laboratory using current techniques. Therefore, culture independent, molecular biological approaches, such as 16S rRNA gene sequence analysis, are essential for the study of aquatic microbial communities in situ. This means that sampling strategies need to be assessed and evaluated specifically for such molecular techniques.

The sea surface microlayer is loosely defined as the upper $1 \mathrm{~mm}$ of the ocean and is the physical boundary between the ocean surface and the lower atmosphere (Liss \& Duce 2005). The sea surface microlayer is physicochemically very different from the underlying subsurface water (Zhang et al. 1998, Zhang et al. 2003, Liss \& Duce 2005), and is a distinct ecosystem which is often referred to as the neuston. A variety of sampling devices are available for examining surface microlayers. The mesh screen sampler (Garrett Screen) is a 
metal or plastic frame supporting a metal or plastic mesh (Garrett 1965). The screen is dipped horizontally in the water and when it is withdrawn the surface microlayer is trapped within the void spaces of the mesh. The screen sampler typically samples depths of 150 to $400 \mu \mathrm{m}$, depending on the size of the mesh used (Carlson 1982). Plate and drum samplers which sample surface microlayers by viscous adhesion to a solid surface have also been developed. The glass plate sampler (typically $20 \times 20 \mathrm{~cm}$ ) is dipped vertically into the water and drawn out slowly. The surface microlayer is then removed from the glass plate using a wiper blade. This samples a depth of 20 to $100 \mu \mathrm{m}$ (Harvey 1965, Harvey \& Burzell 1972). Surface microlayers may also be sampled using hydrophilic (e.g. polycarbonate, PC) and hydrophobic (e.g. polytetrafluoroethylene, PTFE) membranes (typically $47 \mathrm{~mm}$ in diameter), which sample a depth of 1 to $40 \mu \mathrm{m}$ (Crow et al. 1975, Kjelleberg et al. 1979).

Considering that the ocean surface occupies $70 \%$ of the planet's surface, marine surface microlayers represent a large and significant ecosystem connecting the oceans with the atmosphere. Despite this, relatively few studies have used molecular biological techniques to study microbial communities of sea surface microlayers. These few published studies have reported variable results. Studies using PC membranes (depth 30 to $40 \mu \mathrm{m}$ ) to sample surface microlayers have shown clear differences in surface microlayer microbial communities compared to those in subsurface waters ( $0.4 \mathrm{~m}$ below the surface) (Franklin et al. 2005, Cunliffe et al. 2008). However, samples collected using a stainless steel mesh screen (surface microlayer sampling depth not reported) showed no detectable differences between the microbial communities in the surface microlayer and subsurface water $(0.5 \mathrm{~m}$ below the surface) in some areas (Agogue et al. 2005).

Theoretical and empirical evidence suggests that the thickness of the sea surface microlayer is $50 \pm$ 10 (SD) $\mu \mathrm{m}$ (Zhang et al. 1998, Zhang et al. 2003, Liss \& Duce 2005). Samples collected from a range of sites in the South China Sea showed a 'layer of sudden change' for a broad range of chemical and physical parameters (e.g. nutrients, BOD, chl a) at $50 \pm 10 \mu \mathrm{m}$ below the sea surface (Zhang et al. 2003). Therefore, methods that sample below this layer will also collect subsurface waters. When a mesh screen is used to sample to a depth of $400 \mu \mathrm{m}$, the surface microlayer:subsurface sample ratio may be approximately $1: 8$, therefore significantly diluting the surface microlayer in the overall sample and putting into question the representativeness of such a sample for characterising the surface microlayer. This 'dilution' effect may account for the variable results reported by some researchers when comparing surface microlayer microbial commu- nities with those in subsurface waters (e.g. Agogue et al. 2005).

Previous studies have assessed sampling strategies for traditional microbiological characterisation of the sea surface microlayer but have not assessed membranes for molecular biological analysis of microbes (Carlson 1982, Agogue et al. 2004). The aim of this study was to re-evaluate sampling methods (membranes, the glass plate and the mesh screen) which have inherently different sampling depths, specifically for DNA/PCR-based molecular microbial ecology approaches. We used DGGE to profile 16S rRNA genes of Bacteria present in the surface microlayer samples obtained using these methods. DGGE is an established molecular microbial ecology tool which allows easy and rapid qualitative comparison of community structures between samples (Muyzer et al. 1993, Nocker et al. 2007). Samples were collected at the same time from the Tyne Estuary (Northeast UK). Subsurface water $(0.4 \mathrm{~m}$ below the surface) was simultaneously sampled and its diversity compared with that of surface microlayer samples.

We also sampled 3 sites around the Hawaiian island of Oahu in the Pacific Ocean using PC membranes for sea surface microlayer sampling. Bacterial and archaeal community structures were compared in both the surface microlayer and subsurface $(0.4 \mathrm{~m})$ water samples to further validate the use of PC membranes for surface microlayer sampling and to assess whether Bacteria and Archaea show distinct surface microlayer-specific community structures.

\section{MATERIALS AND METHODS}

Comparison of surface microlayer sampling strategies. Samples were collected during calm conditions (wind speed $<5 \mathrm{~m} \mathrm{~s}^{-1}$ ) from St. Peter's Basin (5 March 2009), which is located in the Tyne Estuary on the northeast UK coast. The river Tyne is a large river (catchment area $2935 \mathrm{~km}^{2}$, mean freshwater discharge $\sim 45 \mathrm{~m}^{3} \mathrm{~s}^{-1}$ ) fed by 2 main tributaries draining largely into peat-dominated catchments. St. Peter's Basin is routinely sampled by the Ocean Research Group at Newcastle University, as part of a long-term strategy of surface microlayer monitoring.

The surface microlayer was sampled using different sampling techniques. Two membranes were used: a hydrophobic (PTFE) membrane (diameter $47 \mathrm{~mm}$, pore size $0.2 \mu \mathrm{m}$, Whatman) and a hydrophilic (PC) membrane (diameter $47 \mathrm{~mm}$, pore size $0.2 \mu \mathrm{m}$, ISOPORE, Millipore). Membranes were placed onto the water surface using forceps and left for $10 \mathrm{~s}$ before being removed and stored in $2 \mathrm{ml} \mathrm{screw} \mathrm{cap} \mathrm{tubes.} \mathrm{To} \mathrm{deter-}$ mine any sampling bias specific to the membranes, 
subsurface water was also sampled using both PTFE and PC membranes. Collecting a subsurface water sample and then sampling using the normal membrane method is problematic as surface microlayers can form very quickly (Williams et al. 1986). Therefore, membranes were sealed in sterile zip lock bags that were then placed below the water surface. The bags were then opened, allowing only subsurface water inside, before being resealed and lifted from the water. The membranes were then removed from the bag using forceps and stored in $2 \mathrm{ml}$ screw cap tubes. A glass plate $(20 \times 20 \times 4 \mathrm{~mm})$ was dipped vertically into the water, drawn out and removed of adhered water using a rubber wiper blade. Before sampling, the glass plate and wiper blade were washed in ethanol $(97 \%$ $\mathrm{v} / \mathrm{v})$. Thirty $\mathrm{ml}$ of water were collected into a sterile bottle before being filtered using a plastic syringe through a Sterivex-GS filter unit (pore size $0.2 \mu \mathrm{m}$, Millipore). The filter was stored at $-20^{\circ} \mathrm{C}$. A mesh screen (16 mesh stainless steel screen, size $275 \times 275 \mathrm{~mm}$ ) was placed below the surface water and lifted horizontally through the surface microlayer. Thirty $\mathrm{ml}$ of sampled water from the mesh screen was processed as the glass plate sample. Subsurface water was sampled by placing a sterile bottle $0.4 \mathrm{~m}$ below the surface and removing the cap. Thirty $\mathrm{ml}$ of subsurface water was filtered and stored as above. Three replicates of the membrane, glass plate, mesh screen and subsurface samples were collected.

DNA extraction and community analysis. DNA was extracted from all the Sterivex-GS filter units using methods described in Cunliffe et al. (2008) with modifications as described below. Reagent volumes for DNA extraction from the membranes stored in $2 \mathrm{ml}$ screw cap tubes are in parentheses. A volume of $1.6 \mathrm{ml}$ $(1 \mathrm{ml})$ of SET lysis buffer $(0.75 \mathrm{M}$ sucrose, $40 \mathrm{mM}$ EDTA, $50 \mathrm{mM}$ Tris-HCl, pH 9) was added to each of the samples, then $180 \mu \mathrm{l}(112 \mu \mathrm{l})$ of lysozyme $(9 \mathrm{mg}$ lysozyme, $9 \mu \mathrm{l}$ of $1 \mathrm{M}$ Tris- $\mathrm{HCl} \mathrm{pH} 8,890 \mu \mathrm{H}_{2} \mathrm{O}$ ) was added to each tube before incubation at $37^{\circ} \mathrm{C}$ for $30 \mathrm{~min}$. After incubation, $200 \mu \mathrm{l}(125 \mu \mathrm{l})$ of sodium dodecyl sulphate $(10 \% \mathrm{w} / \mathrm{v})$ and $55 \mu \mathrm{l}(34 \mu \mathrm{l})$ of proteinase $\mathrm{K}(20 \mathrm{mg}$ proteinase $\mathrm{K}, 50 \mu \mathrm{l}$ of $1 \mathrm{M}$ Tris- $\mathrm{HCl}$ $\mathrm{pH} 8,950 \mu \mathrm{l} \mathrm{H}_{2} \mathrm{O}$ ) were added, followed by incubation at $55^{\circ} \mathrm{C}$ for $2 \mathrm{~h}$. The lysate was then removed, placed into a fresh tube and added with $2 \mathrm{ml}$ of phenol:chloroform:isoamyl alcohol $(25: 24: 1)$. The tube was then mixed gently and centrifuged for $10 \mathrm{~min}$ at $6500 \times \mathrm{g}$. DNA was precipitated with polyethylene glycol 6000 $(30 \% \mathrm{w} / \mathrm{v})$ in $1.6 \mathrm{M} \mathrm{NaCl}$ at room temperature for $2 \mathrm{~h}$. The precipitated DNA was collected by centrifugation for $30 \mathrm{~min}$ at $45000 \times g$ and $15^{\circ} \mathrm{C}$. After washing the DNA pellet in ice-cold ethanol $(80 \% \mathrm{v} / \mathrm{v})$, the DNA pellet was redissolved in $100 \mu \mathrm{l}(50 \mu \mathrm{l})$ of $\mathrm{H}_{2} \mathrm{O}$. DNA quality was assessed by agarose gel electrophoresis and quantified using a spectrophotometer (ND-1000, NanoDrop) (see Table 2) before all DNA samples were diluted to a concentration of $30 \mathrm{ng} \mathrm{\mu l}^{-1}$ and stored at $-20^{\circ} \mathrm{C}$. Only molecular grade reagents were used for DNA extraction. To detect any possible contamination of membranes or contamination during sample processing, the DNA extraction procedure was performed on sterile filters. These were subsequently used for PCR (as described below) and proved to be uncontaminated.

DGGE (Muyzer et al. 1993) was used to compare bacterial communities in the samples collected, with minor modifications of the methods described by Cunliffe et al. (2008).

PCR amplification of bacterial 16S rRNA genes was performed using primers 341F (5'-CCT ACG GGA GGC AGC AG-3') and 518R (5'-ATT ACC GCG GCT GCT GG-3') (Muyzer et al. 1993). Primer 341F has a GC-clamp at the $5^{\prime}$-end. For PCR, a total volume of $50 \mu \mathrm{l}$ was used which contained $20 \mu \mathrm{M}$ dNTP (deoxynucleoside triphosphate), $50 \mathrm{pmol}$ of each primer, $0.75 \mu \mathrm{l}(3.75 \mathrm{U})$ Taq DNA polymerase (Fermentas), $1.5 \mathrm{mM} \mathrm{MgCl}_{2}, 5 \mu \mathrm{l} 10 \times$ PCR buffer (Fermentas) and 30 ng DNA. The PCR programme consisted of initial denaturation at $94^{\circ} \mathrm{C}$ for $5 \mathrm{~min}$, followed by 35 cycles of $95^{\circ} \mathrm{C}$ for $1 \mathrm{~min}$, annealing temperature of 65 to $55^{\circ} \mathrm{C}$ for 20 cycles (reduction of $-0.5^{\circ} \mathrm{C}$ cycle ${ }^{-1}$ ) and $55^{\circ} \mathrm{C}$ for 15 cycles, elongation at $72^{\circ} \mathrm{C}$ for $1 \mathrm{~min}$ and then a final elongation step at $72^{\circ} \mathrm{C}$ for $10 \mathrm{~min}$. A negative control was used for each set of reactions to ensure no contamination.

DGGE was performed with a DCode system (Biorad). Gels were prepared using $10 \%$ (w/v) acrylamide/bisacrylamide with a 30 to $70 \%$ linear denaturant gradient. The gel was run in $1 \times \mathrm{TAE}$ buffer at $60^{\circ} \mathrm{C}$ for a total of $1008 \mathrm{Vh}$ (constant voltage $63 \mathrm{~V}, 16 \mathrm{~h}$ ). Gels were stained with SYBR Gold nucleic acid stain (Invitrogen) before the image was captured on a UV transilluminator (Syngene). Bacterial 16S rRNA gene DGGE profiles were compared using GelCompare II (Applied Maths) by constructing a UPGMA dendrogram from the calculated similarity coefficients using a curvebased Pearson correlation.

Surface microlayer sampling in the Pacific Ocean. Three sites (Kaneohe Bay, Ke'ehi Lagoon and an open ocean site) around Oahu Island in the Pacific Ocean were sampled in August 2006. Water properties at the time of sampling are presented in Table 1. Kaneohe Bay is a large sheltered coral reef/estuarine-dominated bay on the northeastern side of the island (Hunter \& Evans 1995). Ke'ehi Lagoon is an estuarine harbour which is part of Mamala Bay on the south side of the island, and is a shelf that deepens from fringing reefs to a depth of up to $50 \mathrm{~m}$ (Parnell 2001). The sea surface microlayer was sampled using PC membranes (3 mem- 
Table 1. Details of sampling sites and conditions

\begin{tabular}{|lcccc|}
\hline & St. Peter's Basin & Kaneohe Bay & Ke'ehi Lagoon & Open ocean \\
\hline Latitude & $54^{\circ} 57.54^{\prime} \mathrm{N}$ & $21^{\circ} 43.411^{\prime} \mathrm{N}$ & $21^{\circ} 16.508^{\prime} \mathrm{N}$ & $19^{\circ} 57.551^{\prime} \mathrm{N}$ \\
Longitude & $1^{\circ} 34.18^{\prime} \mathrm{W}$ & $157^{\circ} 78.886^{\prime} \mathrm{W}$ & $157^{\circ} 54.129^{\prime} \mathrm{W}$ & $159^{\circ} 49.610^{\prime} \mathrm{W}$ \\
Temperature $\left({ }^{\circ} \mathrm{C}\right)$ & 5 & 27 & 27 & 26 \\
Salinity & 7 & 35 & 15 & 35 \\
Offshore distance $(\mathrm{km})$ & 0.01 & 0.03 & 1.85 & 185 \\
Seabed & Sediment & Coral reef & $\sim 5$ & Coral/sand \\
Water depth $(\mathrm{m})$ & $\sim 5$ & $\sim 20$ & $>1000$ \\
\hline
\end{tabular}

branes pooled per sample, depth sampled ca. top $40 \mu \mathrm{m})$ and the underlying subsurface water was sampled as described above. PC membranes were chosen because they are easy to handle and are convenient when sampling at sea from small boats. PFTE membranes are stiff and have proven to be difficult to manage, especially when only short sampling windows are available. All samples were collected from the side of a rigid inflatable boat during calm conditions (wind speed $<5 \mathrm{~m} \mathrm{~s}^{-1}$ ) and stored at $-20^{\circ} \mathrm{C}$ until processed.

DNA extraction and subsequent processing were also performed as described above. PCR amplification and DGGE of archaeal 16S rRNA genes were also undertaken as well as bacterial 16S rRNA gene DGGE. Archaeal 16S rRNA gene PCR required a nested approach using primers 109F and 958R (DeLong 1992, Jurgens et al. 1997) followed by $\mathrm{SA} 1 \mathrm{~F}^{\mathrm{GC}}, \mathrm{SA} 2 \mathrm{~F}^{\mathrm{GC}}$ and PARCH519R (Ovreas et al. 1997, Nicol et al. 2003). The PCR programmes for the archaeal 16S rRNA genes followed the same protocol as before but the annealing temperature of the first round (primers 109F and 958R) was $45^{\circ} \mathrm{C}$ while that of the second round (primers $\mathrm{SA} 1 \mathrm{~F}^{\mathrm{GC}}, \mathrm{SA} 2 \mathrm{~F}^{\mathrm{GC}}$ and PARCH519R) was $53.5^{\circ} \mathrm{C}$.

\section{RESULTS}

\section{Comparison of surface microlayer sampling strategies}

DGGE of bacterial 16S rRNA gene PCR amplicons of replicate samples from St. Peter's Basin (Tyne Estuary) shows each of the sampling techniques to be reproducible (Fig. 1A). Replicates were pooled to produce a composite DGGE image for each sampling technique (Fig. 1B). Bacterial communities sampled using membranes (only the surface microlayer) were different from both those obtained using the other methods and those in subsurface water (similarity $78 \%$ ), forming a distinct clade in the dendrogram (Fig. 1C). Similarity of samples collected from the surface microlayer using the hydrophilic and hydrophobic membranes was determined using an objective computer programme.
This revealed that both profiles showed $90 \%$ similarity (Fig. 1C). The bacterial communities determined using the glass plate, mesh screen and subsurface sampling methods were similar (similarity $\geq 92 \%$ ) (Fig. 1C).

To determine if there was any membrane-specific bias during the sampling procedures, the subsurface water (excluding any surface microlayer) was also sampled using the same membranes. The bacterial communities from the subsurface samples collected with membranes were similar to those from subsurface samples collected using the submerged bottle but not to those from membrane-collected surface microlayer samples (Fig. 1A-C). This provides strong evidence that there is no membrane-specific bias during sampling of the bacterial community which is in agreement with previous studies (Franklin et al. 2005).

Previous studies comparing microbial communities in operationally defined surface microlayers with those in associated subsurface waters have produced variable results (Agogue et al. 2005, Franklin et al. 2005, Auguet \& Casamayor 2008, Cunliffe et al. 2008). Our current data (Fig. 1) show that samples collected using the glass plate and mesh screen do not show distinct community differences compared to subsurface water. Only those samples collected using membrane filters, i.e. the top $42 \mu \mathrm{m}$, show distinct community differences. Considering current evidence which suggests that the surface microlayer is $50 \pm 10 \mu \mathrm{m}$ thick (Zhang et al. 1998, Zhang et al. 2003, Liss \& Duce 2005), our data strongly support our earlier contention of distinct surface microlayer communities.

\section{Comparison of Pacific Ocean surface microlayer community structures using membrane samplers}

DNA extracted from the surface microlayer and subsurface water samples from around Oahu Island (Table 1, Fig. 2) was used as template for PCR with primers targeting bacterial and archaeal 16S rRNA genes. This was followed by DGGE of the PCR amplicons in order to compare the total patterns of bacterial and archaeal communities present. 

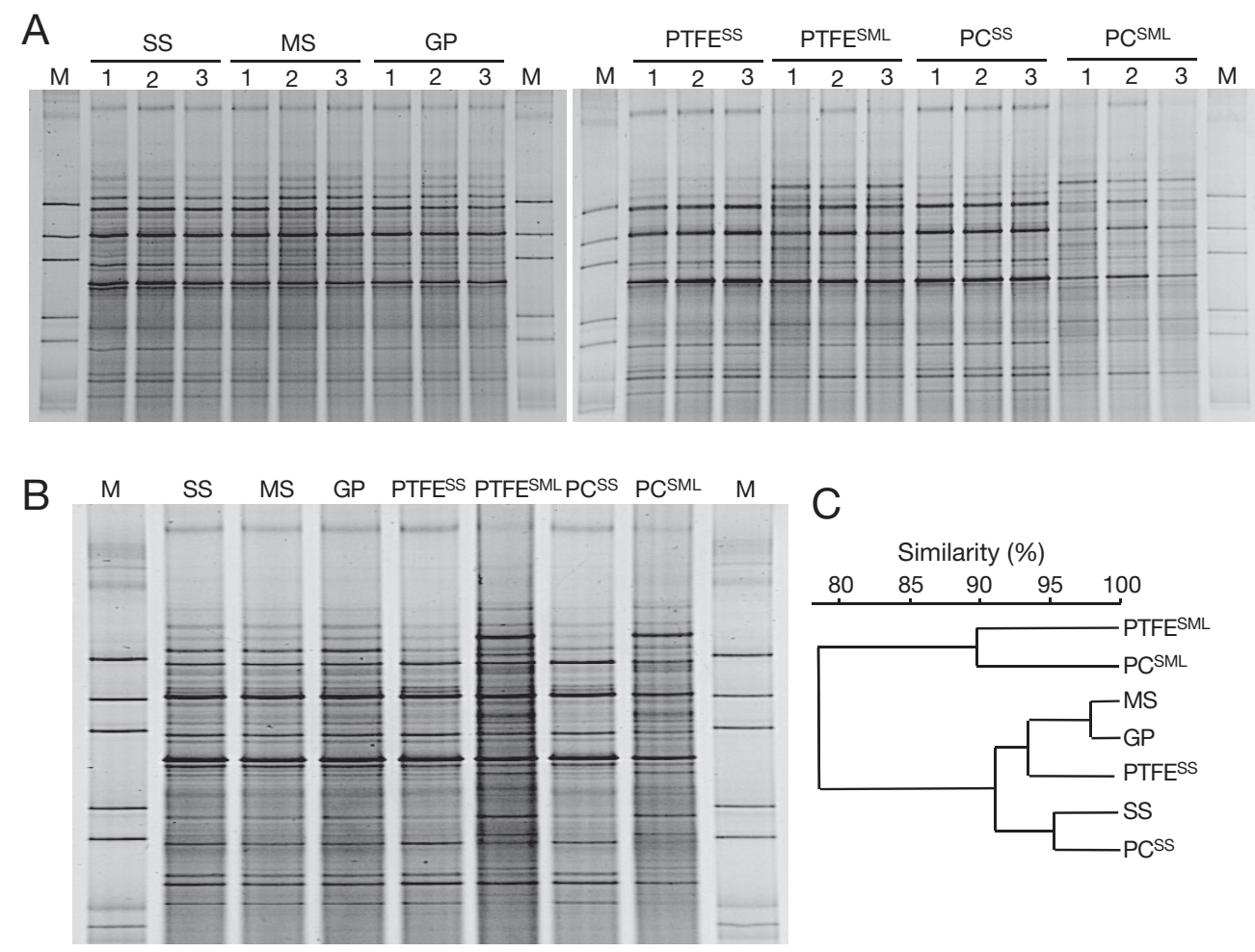

Fig. 1. (A) DGGE profiles of 16S rRNA gene PCR amplicons of Bacteria showing bacterial community structures of triplicate samples (numbered 1-3) collected with different surface microlayer sampling devices. Hydrophobic membranes were used to sample the surface microlayer (PTFE ${ }^{\mathrm{SML}}$ ) and subsurface waters $\left(\mathrm{PTFE}^{\mathrm{SS}}\right)$, as were hydrophilic membranes $\left(\mathrm{PC}^{\mathrm{SML}}\right.$ and $\left.\mathrm{PC}^{\mathrm{SS}}\right)$. Samples were also taken from the surface using a glass plate (GP) and a mesh screen (MS), and from the subsurface waters using a submerged bottle (SS). M is a DGGE marker created from a bacterial 16S rRNA clone library. (B) DGGE profiles from pooled PCR amplicons from all replicate samples in A. (C) Dendrogram showing the similarity of bacterial community structures in B

\section{Bacterial community structures}

Banding patterns of bacterial 16S rRNA gene PCR amplicons from DGGE and subsequent pattern cluster analysis indicated that the bacterial communities in the surface microlayer and subsurface waters were not randomly distributed (Figs. $3 \& 4$ ). There was a high degree of similarity between duplicate samples from each site (Fig. 4). Bacterial community structures in samples collected from the surface microlayer of both Kaneohe Bay and Ke'ehi Lagoon were more similar to

Table 2. Sampling parameters for methods comparison at St. Peter's Basin. PTFE: polytetrafluoroethylene, PC: polycarbonate

\begin{tabular}{|lccc|}
\hline & $\begin{array}{c}\text { Sampling } \\
\text { depth }(\mu \mathrm{m})\end{array}$ & $\begin{array}{c}\text { Sample volume } \\
(\text { mean } \pm \text { SD, ml) }\end{array}$ & $\begin{array}{c}\text { DNA yield (mean } \\
\left. \pm \mathrm{SD}, \mu \mathrm{g} \mathrm{l}^{-1}\right)\end{array}$ \\
\hline PTFE & 6 & $0.11 \pm 0.07$ & $42 \pm 4.00$ \\
PC & 42 & $0.72 \pm 0.45$ & $40 \pm 2.40$ \\
Glass plate & 150 & $30 \pm 0.00$ & $13 \pm 2.00$ \\
Mesh screen & 400 & $30 \pm 0.00$ & $18 \pm 6.11$ \\
Subsurface & 400000 & $30 \pm 0.00$ & $12 \pm 1.00$ \\
\hline
\end{tabular}

each other ( $87 \%$ similarity) than to the bacterial community structures of their cognate subsurface $(0.4 \mathrm{~m})$ samples. The subsurface bacterial community structures from both Kaneohe Bay and Ke'ehi Lagoon were also similar to each other ( $88 \%$ similarity).

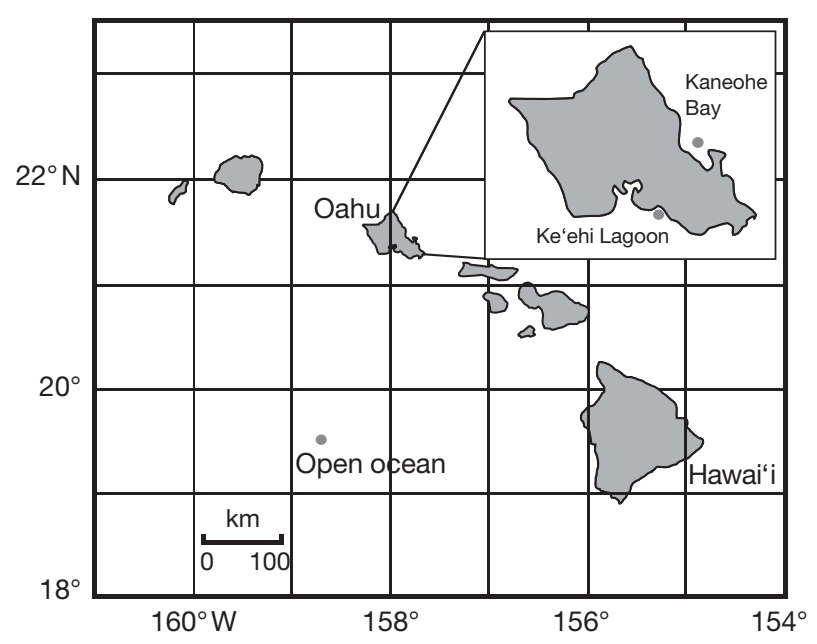

Fig. 2. Location of sampling sites around Oahu Island in the Pacific Ocean 

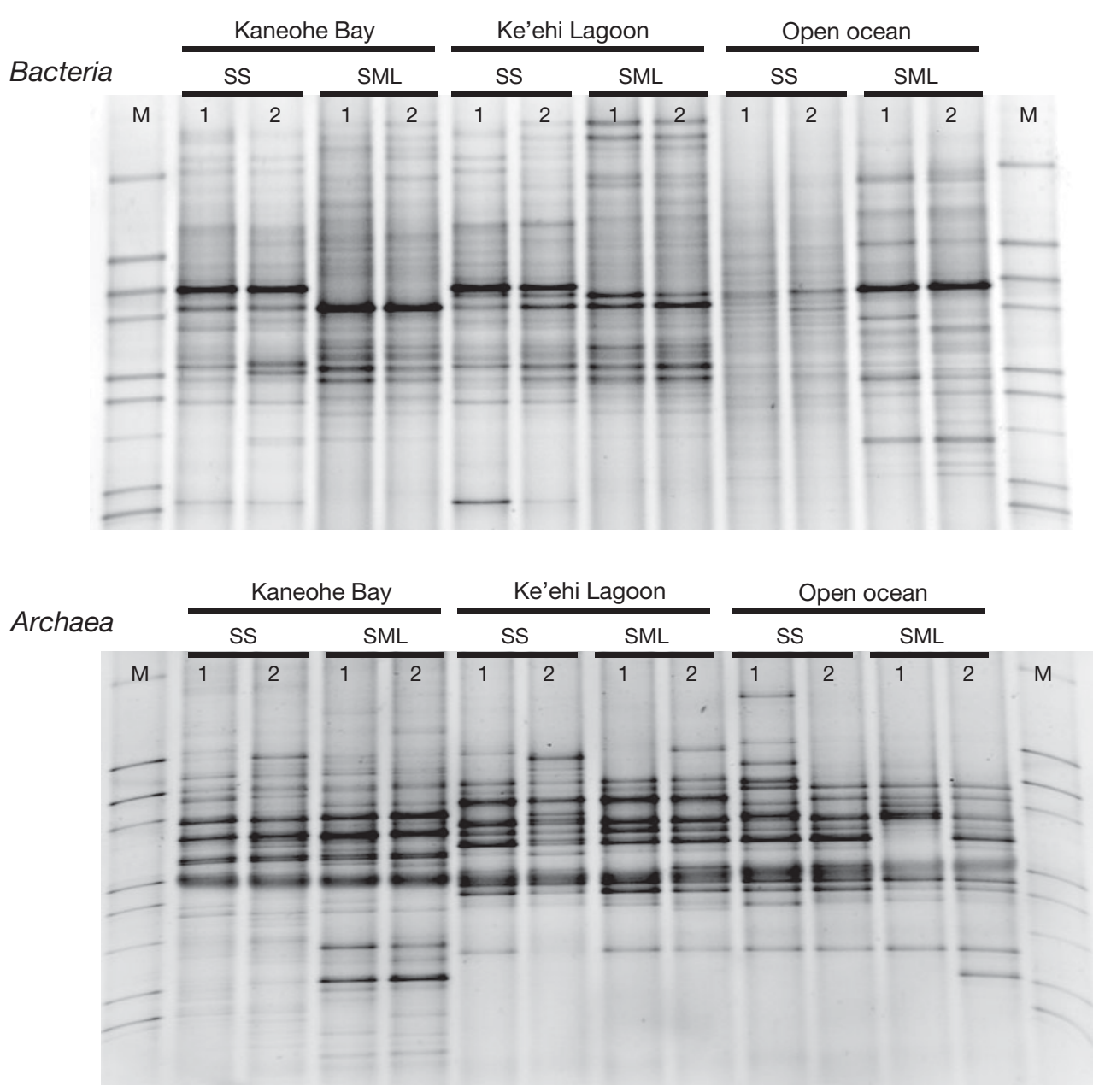

Fig. 3. DGGE profiles of 16S rRNA gene PCR amplicons of Bacteria and Archaea showing community structures in samples collected from the surface microlayer (SML) using hydrophilic membranes and from subsurface water (SS) at 3 sites around Oahu Island in the Pacific Ocean. M is a DGGE marker created from a bacterial 16S rRNA clone library. Lane numbers show each sample replicate

Bacterial communities in the subsurface water and surface microlayer samples collected from the open ocean site were distinctly different from those collected at the 2 coastal sites (Figs. $3 \& 4$ ). The open ocean site showed different bacterial community structures in the surface microlayer compared to the underlying subsurface water, supporting the observations made at Kaneohe Bay and Ke'ehi Lagoon (Figs. 3 \& 4).

\section{Archaeal community structures}

In conjunction with the bacterial 16S rRNA gene banding pattern assessment, archaeal community structure using archaeal 16S rRNA gene banding patterns was also determined from the same samples. The community patterns for Archaea were different from those of Bacteria over the sites sampled (Figs. $3 \& 4$ ). Unlike the Bacteria, archaeal community structures at Kaneohe Bay and Ke'ehi Lagoon were not similar. Archaeal communities at Kaneohe Bay and Ke'ehi Lagoon were distinctly different, with the Ke'ehi Lagoon archaeal communities being similar in structure to the open ocean archaeal communities sampled. At Kaneohe Bay, samples collected from the surface microlayer and subsurface waters showed some differences, mainly because of 2 extra dominant DGGE bands in the surface microlayer profiles (Fig. 3). The archaeal communities at Ke'ehi Lagoon showed no clear differences between the surface microlayer and the subsurface samples, unlike bacterial communities in the Ke'ehi Lagoon samples, indicating no surface microlayer-specific effects on archaeal community structure (Fig. 4). 

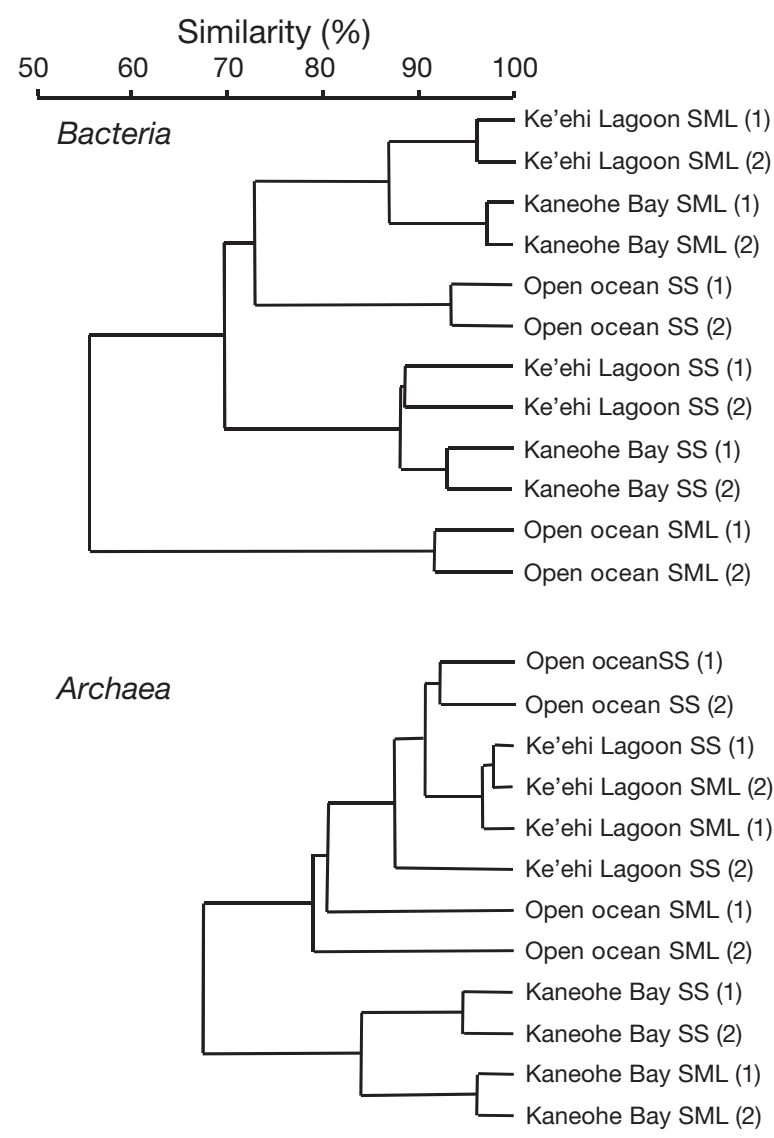

Fig. 4. Dendrograms showing the similarity of DGGE profiles of 16S rRNA gene PCR amplicons of Bacteria and Archaea (Fig. 3) from samples collected from the surface microlayer (SML) and subsurface water (SS) at 3 sites around Oahu Island in the Pacific Ocean. Numbers in parentheses show the sample replicate number and indicate that replicate samples are highly similar to each other

\section{DISCUSSION}

The effect of different surface microlayer sampling methods on the results of bacterial community analysis has only been addressed in 1 previous study. Agogue et al. (2004) made detailed comparisons of a broad range of parameters with samples taken with mesh screen and glass plate samplers. The authors also included membranes for some, but not for all parameters due to limitations of the sample volume collected. Membranes were not included in their molecular biological comparison of bacterial community structures. Agogue et al. (2004) used DGGE and single strand conformation polymorphism (SSCP) to compare bacterial community structures in DNA samples collected using a mesh screen and a glass plate. The authors reported no differences between bacterial communities obtained with mesh screens and glass plates. Similarly, in the present study, we also detected no differences between bacterial communities in surface microlayer samples obtained using the mesh screen and the glass plate when compared to each other and to subsurface water. However, we detected differences between these samples and those collected with membranes.

As outlined earlier, in the few studies that have used molecular biological techniques to study microbial communities in aquatic surface microlayers, variable results have been reported in terms of differences in bacterial community structures in the surface microlayer compared to subsurface water (Agogue et al. 2005, Franklin et al. 2005, Cunliffe et al. 2008). The conclusions presented in this study directly impact the interpretation of results from these other surface microlayer studies. Conclusions that surface microlayer communities are the same as those in underlying subsurface waters, based on analysis of samples containing both surface microlayer and subsurface water, should therefore be considered with caution.

The similarity of bacterial community structures in the surface microlayers at Kaneohe Bay and Ke'ehi Lagoon and their distinct differences from their cognate subsurface waters suggest that the determinants of bacterial community structure in the surface microlayer have similar effects on opposite shores of Oahu Island. Coastal zones are influenced by multiple water sources, including groundwater seepage, terrestrial runoff and oceanic water. Both Kaneohe Bay and Ke'ehi Lagoon are strongly influenced by Oahu Island processes (Hunter \& Evans 1995, Parnell 2001), which may impact the surface microlayer and subsurface communities studied. This was evident in Ke'ehi Lagoon during sampling where the salinity was 15, indicating a significant source of freshwater into the lagoon (Table 1).

Water movements around both Kaneohe Bay and Ke'ehi Lagoon are tidally driven and oriented along the shoreline. The semi-diurnal tide approaches Oahu Island from the northeast, separates close to Kaneohe Bay and travels around the island converging in Mamala Bay, therefore directly connecting the Kaneohe Bay and Ke'ehi Lagoon water masses (Larsen 1977, Hamilton et al. 1995). Thus, it is impossible to distinguish in the present study to what extent the Kaneohe Bay and Ke'ehi Lagoon samples are independent other than geographically.

In the present study, both domains (Bacteria vs. Archaea) behaved differently in that bacterial communities of the surface microlayer were similar on the 2 sides of the island, but archaeal communities were not. These fundamentally different patterns of community composition can neither be explained by the tidal currents, nor can sampling alone be responsible for the surface microlayer-specific community structures reported. 
Our data further support the hypothesis that the microbial community structure of the surface microlayer is different from that of subsurface water only a few centimetres below, particularly in the case of the bacterioneuston, (Franklin et al. 2005, Cunliffe et al. 2008) and validate the use of $\mathrm{PC}$ membranes to sample the surface microlayer for microbiological analysis.

Archaea are globally widespread and are a significant component of marine ecosystems (Massana et al. 2000, Ouverney \& Fuhrman 2000). It remains unclear why in the present study Bacteria responded more markedly to the sea surface microlayer habitat than Archaea. A recent study showed that archaeal communities in surface microlayer samples collected from 10 mountain lakes were dominated by Crenarchaeota while subsurface samples (in the underlying first $1 \mathrm{~m}$ of the water column) were mostly Euryarchaeota (Auguet \& Casamayor 2008). It has been postulated that there are distinct differences between Archaea and Bacteria such as physiological flexibility, which may influence their ecology and diversity in different habitats (Aller \& Kemp 2008). The present data clearly suggest that the ecological responsiveness of the 2 domains to the sea surface microlayer environment differs, and this impacts relative diversity. Future work should aim to establish what these ecological distinctions are, using phylogenetic and functional diversity approaches.

Caution must be exercised when interpreting data from samples collected using mesh screens and glass plates that may contain subsurface water in addition to the surface microlayer. The critical point is that membranes sample only less than the top $50 \mu \mathrm{m}$ of the surface microlayer while other methods do not.

It is important to consider the practicalities of sampling surface microlayers, especially when collecting samples at sea. Glass plates and particularly mesh screens are large and can be difficult to handle from small boats (e.g. Zodiac). They are also difficult to clean and sterilise before and between samplings. Contamination is a critical point when using molecular biological approaches such as PCR. Membranes are inexpensive, easy to use because of their small size and are far less susceptible to contamination.

We believe that the quest for the best sampling strategy for molecular microbial ecological studies of surface microlayers is not yet complete. Membranes are not perfect sampling devices because they collect relatively small sample volumes, which are suitable for only a limited number of downstream techniques, particularly PCR. Moreover, membranes may not be suitable for downstream quantification purposes such as cell counts due to their selective adsorption properties (Agogue et al. 2004). Future work needs to refine existing methods and develop new sampling strategies that allow surface microlayer-specific sampling without bias and without contamination with subsurface water. These sampling techniques must also be practical and compatible with molecular biological-based analysis and allow easy deployment at sea. We recommend that membranes be used for sampling surface microlayers for DNA/PCR-based molecular approaches that seek to define microbial communities in the surface microlayer of oceans and other aquatic environments.

Acknowledgements. This work was supported by the UK Natural Environment Research Council (NERC) through the project 'The role of the bacterioneuston in air-sea gas exchange' (NE/C001923/1), which is part of the UK Surface Ocean Lower Atmosphere Study (UK-SOLAS) directed programme. We also thank the Agouron Institute and the University of Hawaii for allowing E.H. to collect surface microlayer and subsurface water samples during the Microbial Oceanography Summer Course in 2006.

\section{LITERATURE CITED}

Agogue H, Casamayor EO, Joux F, Obernosterer I and others (2004) Comparison of samplers for the biological characterization of the sea surface microlayer. Limnol Oceanogr Methods 2:213-225

Agogue H, Casamayor EO, Bourrain M, Obernosterer I, Joux F, Herndl GJ, Lebaron P (2005) A survey on bacteria inhabiting the sea surface microlayer of coastal ecosystems. FEMS Microbiol Ecol 54:269-280

Aller JY, Kemp PF (2008) Are Archaea inherently less diverse than Bacteria in the same environments? FEMS Microbiol Ecol 65:74-87

- Auguet JC, Casamayor EO (2008) A hotspot for cold Crenarchaeota in the neuston of high mountain lakes. Environ Microbiol 10:1080-1086

- Carlson DJ (1982) A field evaluation of plate and screen microlayer sampling techniques. Mar Chem 11:189-208

Crow SA, Ahern DG, Cook WL, Bourquin AW (1975) Densities of bacteria and fungi in coastal surface films as determined by a membrane-adsorption procedure. Limnol Oceanogr 20:644-646

Cunliffe M, Schafer H, Harrison E, Cleave S, Upstill-Goddard RC, Murrell JC (2008) Phylogenetic and functional gene analysis of the bacterial and archaeal communities associated with the surface microlayer of an estuary. ISME J 2:776-789

$>$ DeLong EF (1992) Archaea in coastal marine environments. Proc Natl Acad Sci USA 89:5685-5689

> Franklin MP, McDonald IR, Bourne DG, Owens NJ, UpstillGoddard RC, Murrell JC (2005) Bacterial diversity in the bacterioneuston (sea surface microlayer): the bacterioneuston through the looking glass. Environ Microbiol 7:723-736

Garrett WD (1965) Collection of slick-forming materials from the sea surface. Limnol Oceanogr 10:602-605

Giovannoni SJ, Stingl U (2005) Molecular diversity and ecology of microbial plankton. Nature 437:343-348

Hamilton P, Singer J, Waddell E (1995) Ocean current measurements. In: Colwell R, Orlob G, Schubel J (eds) Mamala Bay study. Mamala Bay Study Commission, Honolulu, HI

Harvey GW (1965) Microlayer collection from the sea surface. A new method and initial results. Limnol Oceanogr 11: $608-613$ 
Harvey GW, Burzell LA (1972) A simple microlayer method for small samples. Limnol Oceanogr 11:156-157

Hunter CL, Evans CW (1995) Coral reefs in Kaneohe Bay, Hawaii: two centuries of western influence and two decades of data. Bull Mar Sci 57:501-515

Jurgens G, Lindstrom K, Saano A (1997) Novel group within the kingdom Crenarchaeota from boreal forest soil. Appl Environ Microbiol 63:803-805

Kjelleberg S, Stenstrom TA, Odham G (1979) Comparative study of different hydrophobic devices for sampling liquid surface films and adherent microorganisms. Mar Biol 53: $21-25$

Larsen JC (1977) Cotidal charts for the Pacific Ocean near Hawaii using f-plane solutions. J Phys Oceanogr 7: 100-109

Liss PS, Duce RA (2005) The sea surface and global change. Cambridge University Press, Cambridge

- Massana R, DeLong EF, Pedros-Alio C (2000) A few cosmopolitan phylotypes dominate planktonic archaeal assemblages in widely different oceanic provinces. Appl Environ Microbiol 66:1777-1787

Muyzer G, de Waal EC, Uitterlinden AG (1993) Profiling of complex microbial populations by denaturing gradient gel electrophoresis analysis of polymerase chain reactionamplified genes coding for 16S rRNA. Appl Environ Microbiol 59:695-700

> Nicol GW, Glover LA, Prosser JI (2003) The impact of grassland management on archaeal community structure in upland pasture rhizosphere soil. Environ Microbiol 5:152-162

Editorial responsibility: Jed Fuhrman,

Los Angeles, California, USA
Nocker A, Burr M, Camper AK (2007) Genotypic microbial community profiling: a critical technical review. Microb Ecol 54:276-289

Ouverney CC, Fuhrman JA (2000) Marine planktonic Archaea take up amino acids. Appl Environ Microbiol 66: 4829-4833

> Ovreas L, Forney L, Daae FL, Torsvik V (1997) Distribution of bacterioplankton in meromictic Lake Saelenvannet, as determined by denaturing gradient gel electrophoresis of PCR-amplified gene fragments coding for 16S rRNA. Appl Environ Microbiol 63:3367-3373

Parnell PE (2001) The distribution of estuarine and oceanic water masses on the southern shore of O'ahu, Hawai'i: ecological and coastal management implications, and novel methodology. Limnol Oceanogr 46: 1468-1485

Williams PM, Carlucci AF, Henrichs SM, Vanvleet ES, Horrigan SG, Reid FMH, Robertson KJ (1986) Chemical and microbiological studies of sea-surface films in the southern Gulf of California and off the west coast of Baja California. Mar Chem 19:17-98

Zhang Z, Liu L, Wu Z, Li J, Ding H (1998) Physicochemical studies of the sea surface microlayer. I. Thickness of the sea surface microlayer and its experimental determination. J Colloid Interface Sci 204:294-299

Zhang Z, Liu L, Liu C, Cai W (2003) Studies on the sea surface microlayer. II. The layer of sudden change of physical and chemical properties. J Colloid Interface Sci 264: $148-159$

Submitted: December 19, 2008; Accepted: June 2, 2009 Proofs received from author(s): August 24, 2009 